\title{
CORRESPONDENCE
}

\section{TILLITE-GRANITE TRANSFORMATIONS}

SIR,-We do not wish to make further comment on Dr. Bowes's reply (Geol. Mag., 1956, p. 18), but should like to bring to notice that from his stratigraphical work in the Mt. Fitton-Mt. Painter region Dr. B. Campana of the South Australian Geological Survey has recently published ${ }^{1}$ conclusions similar to our own.

16th April, 1956.

G. A. Chinner.

M. SANDO.

A. J. R. WhITE.

\section{REVIEW}

Paläontologie und Phylogenie der Niederen Tetrapoden. By FriedRICH VON HUENE. pp. xii +716 with 690 text figures. Gustav Fischer, Jena. 1956. Price DM. 88.

This is a well-produced, generously illustrated account of the extinct amphibia and reptiles, written by a palaeontologist whose reputation has been established among the leaders of the subject for half a century. Professor von Huene, the first of whose three hundred and more publications appeared in 1899 , is the foremost authority on the primitive archosaur reptiles, but his researches have ranged into almost every reptilian order and also into the extinct amphibia, and for him to have completed such a work as this at the age of eighty must be held to be a remarkable achievement. The subject is introduced by a discussion of the origin of the tetrapods ; there is an introduction to each order, practically every genus receives at least a mention, and the account is concluded by a discussion and an up-to-date list of references. The discussions are supported by diagrams illustrating taxonomic and morphological matters.

It is somewhat unfortunate that such a work should be published simultaneously with the corresponding volume of the Traité de Paléontologie. As is perhaps to be expected in a work of such magnitude carried out by a single writer, there are errors of reference and figures are sometimes ascribed to the wrong author. Scales are seldom given in the text figures and the index is unfortunately confined to generic names. Nevertheless, in the present state of flux of so many groups, this volume will be welcomed as a valuable contribution to the subject, and the author's opinion of the numerous problems which are involved will be of great interest to specialists.

F. R. P.

1 Campana, B. (1955). "The Stratigraphy of the Northern Flinders Ranges and the Alleged Granitisation of Tillite in the Mt. Fitton Area." Austr. Journ. Sci., xviii, No. 3, pp. 75-7. 